UDC 339.7:339.9

\title{
The role of foreign direct investment in economic growth of Nigeria
}

\author{
Michael Madojemu \\ Peoples' Friendship University of Russia (RUDN University) \\ 6 Miklukho-Maklaya St, Moscow, 117198, Russian Federation
}

\begin{abstract}
The paper investigates the relevance of foreign direct investment (FDI) as a factor inhibiting economic growth in Nigeria. This paper inspects the sectorial influence of FDI in manufacturing, mining, oil and the telecommunications sectors on economic growth in Nigeria based on theoretical framework founded on the standard growth accounting theory, detailed analysis of the sectorial FDI over the period 1981 and 2017 was carried out. Various econometric methods are employed, such as the ADF test, Dickey and Fuller test (1979), PP test (Phillips and Perron, 1988) are used for the unit root test, and the Shahbaz and Rahman (2010) method is used for the long-run relationship between the foreign direct investment and economic growth. The paper also adapted the framework provided by M.B. Obwona (2004). The paper formalizes a mechanism of recommendations to allow for the influence of foreign direct investment in the transmission of socio-economic growth generated in Nigeria. In conclusion, government should provide an enabling environment that will encourage foreign investors to invest in Nigeria economy by addressing the security challenges in the country, understanding that investment friendly environment will improved regulatory framework as well as encourage domestic investment.
\end{abstract}

Keywords: FDI, economic growth, economy, Nigeria, sectors of the economy, investment policy

\section{Introduction}

Socio-economic development is a multidirectional procedure which is germane for the sustainability of an economy. According to (Alfaro et al., 2004), it is now recognized that foreign direct investment (FDI) brings growth benefits to developing countries depending on the absorptive dimension of these economies to grasp gains from technology transfer and spillover effects. It is a long-run process whereby the real national income of an economy accelerates over a long period of time. Over a decade, sustainability, survival and acceleration of higher socio-economic development is the primary aims of the emerging nations. In the face of domestic resources deficit in financing socio-economic developmental projects, most emerging countries are relying on external financial sources and assistance from the developed countries. However, it was only in the post war period that a well-structured foreign capital flow began to experience wide recognition and attention, when

(C) Madojemu M., 2020

(c) This work is licensed under a Creative Commons Attribution 4.0 International License https://creativecommons.org/licenses/by/4.0/ 
the western nations started contributing towards the infrastructural development, poverty alleviation, emergency assistance and socio-economic reconstruction of the affected nations.

In the era of socio-economic globalization and integration, the relevant of foreign capital inflows in stimulating the developmental process of emerging nations like Nigeria is very essentials. According to P.R. Edwin (Edwin, 1950), the current global financial issues and the aftermath huge amount transfer in the international capital inflows leads to economic growth of emerging countries K. Sahoo \& N. Sethi (Sahoo, Sethi, 2017) acknowledged that the impact of foreign capital on economic development of developing countries are characterized with low capita income, low saving, and apathy attitude towards investing, shortage of foreign exchange, technological backwardness and poor capital. Some other scientists opined that capital inflows help to solve the problems associated with developing countries as it brings sufficient financial and physical capital, investment for technical know-how, skilled personnel's, advanced production techniques, perfect market information, organizational experience, innovation in products and foreign exchange resources Thus, one of the major determinants of globalization and higher economic growth is through foreign direct investment. Foreign direct investment is one of the ways countries have access to foreign capital from developed nations.

Currently, Nigeria economy has experience relatively steady growth and her gross domestic product (GDP) average growth rate of $5.4 \%$, for the past 30 years. Nigeria is the biggest economy in West Africa, contributing $41 \%$ to the subregion's gross domestic product and largest in Africa followed by Egypt, South Africa and Algeria, contributing 14\% to the continent's GDP. Nigeria is ranked number $8^{\text {th }}$ world producer of crude oil, with oil reserves estimated at about 36 billion barrels and was ranked $46^{\text {th }}$ position in term of purchasing power parity in 2018. In the world today, Nigeria has the $6^{\text {th }}$ largest deposit of natural gas, with a reserve estimated at a minimum of 100 trillion cubic feet. Over 34 minerals deposits were discovered including a large quantity of uranium, vast arable land for farming and about 44 exportable commodities. Nigeria was ranked the $7^{\text {th }}$ richest nation in the world because of her oil revenue which accounted for over $95 \%$ of foreign exchange earnings and about $70 \%$ of budgetary revenues. Nigeria's population serves as the largest market in Africa, thereby providing foreign investors with the opportunities of selling/marketing their goods and services in the country as it also provides an environment for finished products imported into Africa. According to World Population Review (2019), Nigeria has the largest population of an estimate of 195874683 people, followed by Ethiopia with an estimated population of 109224414 people, then Egypt with 98423598 people, DR Congo with 84068091 people and South Africa 57792518 people. Over the years, a huge foreign direct investment has been coming to Nigeria for economic growth and development purposes due to the adoption of new economic reforms and policies like Import Substitution Industrialization Strategy 1960, Farm Settlement Scheme 1960, National Accelerated Food Production Programme, 1972, River Basin Development Act 1976, Land Use Act 1978, Export Promotion Strategy 1986, Structural Adjustment Programme 1987, Agricultural Policy for Nigeria, 1988, Privatization and Commercialization policy of 1988, Agricultural Control on Importation 
1990, Nigerian Investment Promotion Commission 2003 and National Economic Empowerment and Development Strategy (NEEDS) 2004. Qualified foreign organizations were given the opportunities to take over most of these establishments to enhance efficiency. This is because such foreign companies are reported to possess the managerial acumen, technological advancement and technical know-how needed to resuscitate and sustain the weak industries in Nigeria (Umah, 2007).

\section{Literature review}

It is obvious that several economies theories attempted to evaluate the relevance of FDI on socio-economic growth in the country both from positive and negative point of view. Economic theories are like neo-classical theory, dependency theory, and endogenous growth model theory are going to be considered as basic point. According to (Adams, 2009), neoclassical perspective is based on a basic principle in economics, which describe that economic growth requires capital investment in the form of long-term obligation. This is to say that this theory creates a better relationship between the FDI and economy development of every society most in particular developing countries.

The dependency theory maintains that, the poorness of developing countries is due to: imperial neglect; overdependence upon primary products as exports to developed countries; foreign investors' malpractices, particularly through transfer of prince mechanics; foreign firm control of key economic sectors with crowdingout effect of domestic firms; implementation of inappropriate technology in developing countries; introduction of international division of labour to the disadvantage of developing countries; prevention of independent development strategy fashioned around domestic technology and indigenous investors; distortion of the domestic labour force through discriminatory remuneration; and reliance on foreign capital in form of aid that usually aggravated corruption (Aremu, 1997).

However, the controversial issues surrounding the impacts of FDI inflows are as result of the positive and negative findings of extant literature. According to T. Liu and K.W. Li (Liu, Li, 2001) the evidence suggests that FDI not only affects growth directly, but also indirectly through its interaction with human capital. In addition, E. Borensztein, J. Gregorio and J.W. Lee (Borensztein, Gregorio, Lee, 1998), S. Makki and A. Somwaru (Makki, Somwaru, 2004) agree that FDI inflows have been considered as a channel to transfer technologies, knowledge and technical knowhow from the investing countries to the receiving countries. Therefore, on the long run, these conveyance vehicles FDI inflows can exert great positive spillover impacts on the host country's economic growth. Thus, L. Sanjaya and N. Rajneesh (Sanjaya, Rajneesh, 2004), H. Gorg and D. Greenaway (Gorg, Greenaway, 2004), noticed that, besides spillover effects as enhancing human labor's skills, technological transfusion, expanded international market, membership of the global trading and production of multinational corporations, FDI inflows also resolves capital constraints in host countries. Negatively, M. Agosin and R. Machado (Agosin, Machado, 2005), and O. Oyinlola (Oyinlola, 1995) reveals that FDI firms are rivalry to the domestic resources (labor, capital, and land), market shares, and the profit scales of domestic firms since is a form of private capital inflow conducted by a normal competitive firm. Thus, besides the FDI firm's activities of seeking profits, 
they may exert positive effects in the host countries such as boosting exports, employment, technological transfusion, and eventually economic growth. At the same time, FDI firms can also exert some adverse effects such as crowding out the domestic production factors (labor, land and physical capital) and competing against the host countries' firms for profits. Nevertheless, in a certain period of economic growth for developing countries, the net impact of the FDI has been observed positively, it is worth more for a developing economy to attract FDI inflows. A.E. Akinlo (Akinlo, 2004) had a neutral finding, believing that FDI neither affects economic growth and development positively or negatively.

Examining other variables that could explain the interaction between FDI and growth, O. Olofsdotter (Olofsdotter, 1998) opines that the beneficiary effects of FDI are stronger in those countries with higher level of institutional capability. He further emphasized the importance of bureaucratic efficiency in enabling FDI effects. E. Boldeanu and L. Constantinescu (Boldeanu, Constantinescu, 2015) opine that determinants of economic growth as interrelated factors that influence the growth rate of an economy. They went further to establish that there are six known factors that are classified as such out of which four were labeled direct factors. However, back-down that there is no consensus on the key determinants of growth. Political and social factors, technological advancement, capital formation, natural resources and human resource and its quality are some of the determinant factors of socioeconomic growth and development and foreign direct investment could help resolve this entire problem.

\section{Methodology}

The paper aims to examine the relevance of FDI to economic growth in the short and long run in lower-middle-income in Nigeria. Hence, various relevant methodologies are employed to examine the impact of Nigeria variable foreign direct investment on economic growth. Those employed estimation techniques are used to investigate the stationary or cointegration issue, or to estimate the long-run relationship. In particular, the ADF test (Dickey, Fuller, 1979), PP test (Phillips, Perron, 1988) are used for the unit root test, and the Shahbaz and Rahman (2010) method is used for the long-run relationship between the foreign direct investment and economic growth. The paper also adapted the framework provided by M.B. Obwona (Obwona, 2004) to suite the objectives of the paper.

To this end, the paper reviewed and applied the work of M. Shahbaz and M.M. Rahman (Shahbaz, Rahman, 2010) to test for the relevance of FDI on economic growth. The proposed empirical model is expressed by the following formula.

$$
L G D P C_{i t}=\beta_{0}+\beta_{1} F D I_{i t}+\beta_{2} M_{2 i t}+\beta_{3} P R V T_{i t}+\beta_{4} C A P_{i t}+\beta_{5} S E C P_{i t}+\varepsilon_{i t},
$$

where $\beta_{0}$ is the intercept; $\beta_{1}, \beta_{2}, \beta_{3}, \beta_{4}, \beta_{5}$ respectively are estimation coefficients to be estimated; $G D P_{t}$ - is the rate of Nigeria's real GDP growth, this is the dependent variable; $F D I_{t}$ - is the ratio of FDI inflows to Nigeria's GDP, the coefficient (elasticity) is expected to be positive in long run model as a rise in the level of FDI is expected to positively contribute to socio-economic development and economic growth; $G E X_{t}$ - is the ratio of government expenditure to Nigeria's GDP; 
$R E E R_{t}$ - is the real effective exchange rate, which is calculated, based on the flow of trade between Nigeria and investors of its major trading partners; $T G D P_{t}-$ is the ratio of total trade (exports + imports) to real GDP.

In this case, the current state of Nigeria economy for FDI inflow to real GDP is low due to poor state of the economy after coming out of the recession which took place in 2018, until now the economy for FDI inflow is still poor as there have not been substantial growth. Therefore, considering a test for the variable in the papers in order to determine the hypothesis is not certain until there is a change in the current.

\section{Dynamics and geographical distribution of foreign direct investment in Nigeria}

Nigeria was the largest recipient of FDI in Africa for 2007 and 2008. And she has made significant progress in attracting FDI, taking into account the fact that FDI is impetuous required in order to straighten up the "significant gap with industrialized countries. Recent figures report inflows at 8.6 billion dollars for 2009. FDI in Nigeria has been significantly affected by the development of the oil sector, it's world price and government policies in this section.

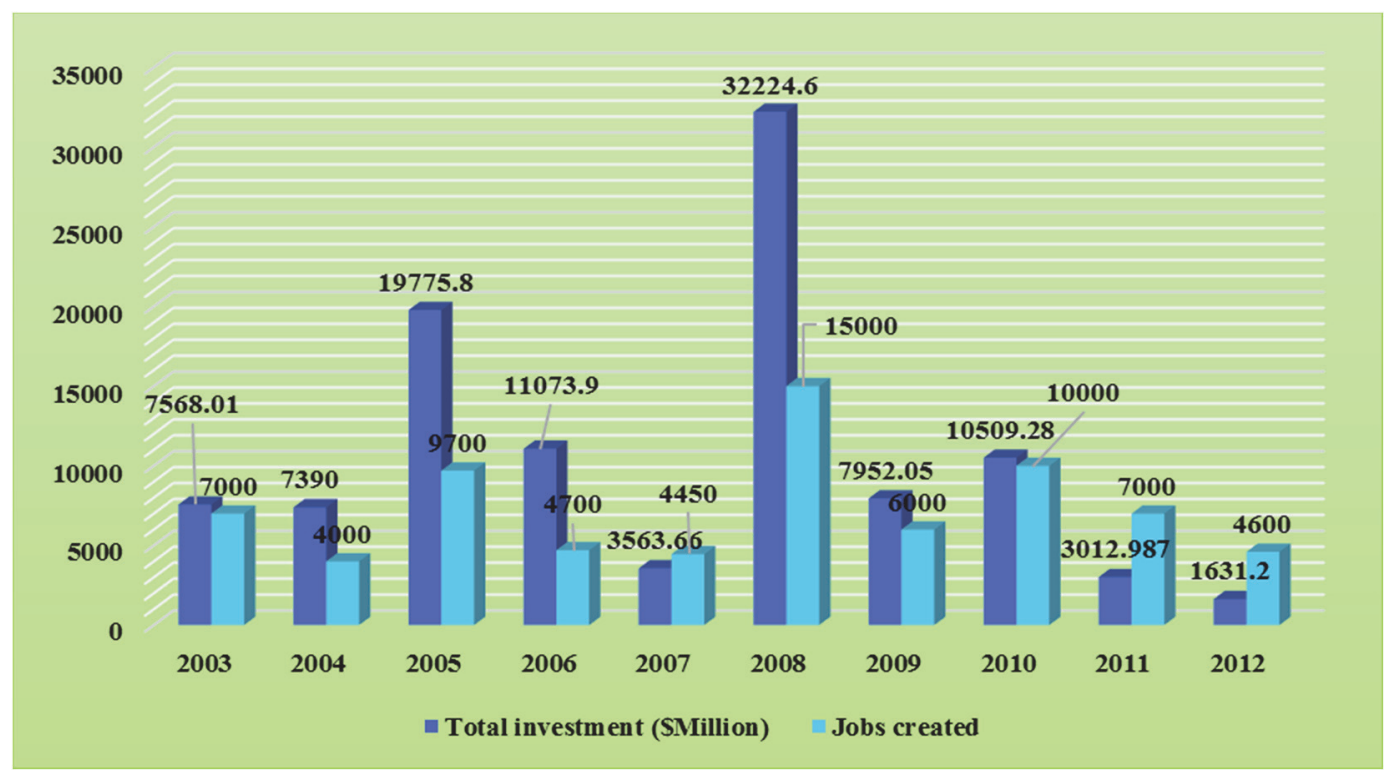

Figure. Distribution of FDIs in Nigeria (2003-2012) using total investments and created employment (jobs)

Source: Research on Humanities and Social Sciences.

The data in figure shows a bell-shaped curve where FDIs is highest in 2008 using total investments (\$ million) and number of created jobs as parameters. It has a net value of over 32 billion and employs about 15400 in that year alone. From the data in this figure, it can be discerned that there is a decline in FDIs in both net value and total jobs created down to 2012. It is not exactly clear what may have led to this since a more reliable business climate was perceived as this period marks the beginning of democracy in 2009. However, as at 2015, Nigeria was leading all African countries in the net value of FDIs attracted to herself till date. 
A crucial aspect to be observed is the geographical distribution of FDI on development regions. Fascinated by the high rates of return, investors from all over the globe have now set their watch on The Federal Republic of Nigeria. As Africa's most populous country and the greatest economy in Africa, Nigeria also boasts the continent's second largest oil reserves and has a very promising growth outlook. Poised to eclipse Africa's largest economy by 2015, Nigeria is becoming a rather worthy recipient of foreign capital, receiving anywhere from 10-12 billion per year. However, in order to take full convenient of what foreign investment has to offer, Nigeria must first upgrade its economic and political climate.

For Nigeria, relevant, long-running economic growth and development is almost entirely possible upon securing substantial amounts of foreign direct investment. FDI, as it is called, is crucial for the Nigerian economy, as it permits the shift of technology and facilitates improvements in productivity. In the long run, this can help counter Nigeria's widespread poverty by increasing per capita income and elevating overall standards of living.

To be sure, Nigeria has a laborious road ahead should it want to achieve the economic growth and stability that it seeks. Nigeria's development plan is simple in theory, yet rather inconvenient in practice given its poor track record. Due to its history of economic mismanagement, corruption, inept leadership, political instability, and poor infrastructure, Nigeria has numerous impediments that collectively deter foreign investment. Thus, at a fundamental level, Nigeria needs to create an environment that is helpful to foreign investment and wholesome economic growth.

Table 1

Foreign direct investment (million dollars, \%)

\begin{tabular}{lccc}
\hline \multicolumn{1}{c}{ Foreign direct investment } & $\mathbf{2 0 1 6}$ & $\mathbf{2 0 1 7}$ & $\mathbf{2 0 1 8}$ \\
\hline FDI Inward Flow & 4,449 & 3,503 & 1,997 \\
FDI Stock & 94,184 & 97,687 & 99,685 \\
Number of Greenfield Investments & 51 & 36 & 55 \\
FDI Inwards (in \% of GFCF***) & 9,2 & $\mathrm{n} / \mathrm{a}$ & $\mathrm{n} / \mathrm{a}$ \\
FDI Stock (in \% of GDP) & 23,2 & $\mathrm{n} / \mathrm{a}$ & $\mathrm{n} / \mathrm{a}$ \\
\hline
\end{tabular}

Source: UNCTAD, 2019.

Table 1 describe Inward FDI Performance Index based on a ratio of the country's share in global FDI inflows and its share in global GDP. The Inward FDI Potential Index is based on 12 economic and structural variables such as GDP, foreign trade, FDI, infrastructures facility, energy consumed, R \& D, education, country risk. Greenfield Investments are a form of foreign direct investment where a parent company starts a new venture in a foreign country by constructing new operational facilities from the ground up. Gross Fixed Capital Formation calculate the value of inclusion to fixed assets purchased by business, government and households less disposals of fixed assets sold off or scrapped.

\section{Results}

The descriptive statistics or analysis of the aggregate FDI and sectoral GDP between 1981 and 2017 is summarized in Table 2. The mean value of the total FDI over the period is 369 billion while the vale ranges between 0.15 billion and 1360 bil- 
lion dollars. The maximum value corresponds to the 2017 estimates. Manufacturing GDP ranges between 26.99 billion dollars and 10.04 trillion dollars with a mean value of 2.15 trillion dollars. The manufacturing GDP ranks after the oil GDP which ranges between 4.28 billion and 11.32 trillion with an average value of 2.82 billion. The telecom sector GDP varies between a minimum value of 23.20 billion and a maximum value of 11.72 trillion with a mean value of 2.37 trillion. The mining sector has the least contribution to GDP with a value that ranges between 3.72 billion and 126 billion and a mean value of 28.17 billion dollars.

Table 2

Descriptive statistics for total FDI and sectoral GDP in billion dollars (1981-2017)

\begin{tabular}{lccccc}
\hline \multicolumn{1}{c}{ Variables } & Obs & Mean. & Std. Dev. & Minimum & Maximum \\
\hline Total FDI & 37 & 369.239 & 465.7861 & 0.15 & 1360.3 \\
Manufacturing Sector GDP & 37 & 2150.25 & 2988.952 & 26.89 & 10044 \\
Oil Sector GDP & 37 & 2820.66 & 3737.197 & 4.28 & 11315 \\
Mining Sector GDP & 37 & 28.1714 & 35.42895 & 3.72 & 126.03 \\
Telecom Sector GDP & 37 & 2373.6 & 3756.85 & 23.2 & 11718 \\
Total GDP & 37 & 24861.4 & 34308.7 & 144.83 & 113712 \\
\hline
\end{tabular}

Source: Akinyemi Ajibola, Muideen Isiaka, Olusogo Ogunleye \& Oluwaseun Adeyemi. NileJBE. December 2018.

Table 2 present the descriptive statistics for total FDI and sectoral GDP between 1981 and 2017. The total GDP ranges between 144.83 billion dollars and 113.71 trillion dollars with a mean value of 24.86 trillion dollars. The next subsection contains the correlation between the growth of FDI and growth of each sector presented in Table 1.

\section{Conclusion and recommendations}

The current administration of President Muhammad Buhari has been working helter-skelter to improve the reputation of the country abroad, and it has started making substantial progress in addressing the issues that have worried foreign investors in the past. The developing countries are believed to be influenced positively with adequate mobilization of FDI into their domestic economies because of the human and material resources employed to bring about more output within the domestic economy. For any country to have sufficient mobilization of FDI, the infrastructural facilities must be made to function efficiently.

Again, foreign borrowing (debt) is not bad in itself except for unproductive uses. Therefore, a country can borrow but not for unproductive and unsound purposes. The contraction of debt for unproductive uses brings about cumulated debt for generations yet unborn which affects the borrowing nation socio-economic growth and development negatively.

It is considered honest that the following policy recommendations would attract more or encourage foreign direct investment that would engineer socio-economic growth and development in Federal Republic of Nigeria.

- Government should continue to pursue trade and foreign exchange policies that would ensure competitiveness of the export sector viability and economic growth. 
- The Nigerian should encourage amidst thriving business environment that would engender economic growth.

- The Nigerian government needs to come up with more friendly economic policies and business environment, which will attract more private, investments (both domestic and foreign) into virtually all the sectors of the economy especially in the areas of infrastructural provision, constructions and agriculture.

- There is need to have a stable political, security and economic environment and improve on the critical infrastructural facilities such as electricity, roads and water level of security at all levels in the country, systems of governance should be based on answerability, lucidity, effective and efficient resource.

- Government efforts should continue in ensuring consistency in policy objectives and instruments through a highly implementation strategy as well as good sense of discipline, understanding and cooperation among the policy makers.

- Government needs to liberalize the foreign sector in Nigeria so that all barriers to trade such as arbitrary tariffs, import and export duties and other levies should be reduced so as to encourage investors.

- The government through the public administrators should develop strong political will in ensuring objective and good utilization of borrowed funds.

- There is need for government to ensure that funds sourced from external borrowings were used for capital investment that can pay itself back with its interest and not recurrent expenditures in order to ensure sustainable growth and development.

\section{References}

Adams, S. (2009). Foreign Direct Investment, Domestic Investment, and Economic Growth in Sub-Saharan Africa. Journal of Policy Modelling, 31(6), 939-949.

Agosin, M., \& Machado, R. (2005). Foreign investment in developing countries: Does it crowd in domestic investment? Oxford Development Studies', Taylor \& Francis Journals, 33(2), 149-162.

Akinlo, A.E. (2004). Foreign direct investment and growth in Nigeria: An empirical investigation. Journal of Policy Modeling, 26, 627-639. https://doi.org/10.1016/j.jpolmod.2004.04.011

Alfaro, L., Chanda, A., Kalemli-Ozcan, S., \& Sayek, S. (2004). FDI and economic growth: The role of local financial markets. Journal of International Economics, 64(1), 89-112.

Aremu, J.A. (1997). Foreign Private Investment: Determinants, Performance and Promotion. CBN Bulletin (pp. 108-112).

Boldeanu, F.T., \& Constantinescu, L. (2015). The main determinants affecting economic growth. Bulletin of the Transilvania University of Braşov. Series V: Economic Sciences, 8(2), 329-338. Retrieved December 282019 from http://webbut.unitbv.ro/BU2015/Series \%20V/BILETIN\%20I/38_Boldeanu\%20Constantinescu.pdf

Borensztein, E., De Gregorio, J., \& Lee, J. W. (1998). How does foreign direct investment affect economic growth? Journal of International Economics, 45(1), 115-135.

Dickey, D.A., \& Fuller, W.A. (1979). Distribution of the estimators for autoregressive time series with a unit root. J. Am. Stat. Assoc., 74, 427-431.

Edwin, P.R. (1950). Foreign capital in economic development: A case study of Japan. The Milbank Memorial Fund Quarterly, 28(2), 173-190.

Gorg, H., \& Greenway, D. (2004). "Much Ado about Nothing? Do Domestic Firms Really Benefits from Foreign Investment? The World Bank Research Observer, 19, 171-197.

Liu, T., \& Li, K.W. (2001). Impact of liberalization of financial resources in China's economic growth: evidence from provinces. Journal of Asian Economics, 12(2), 245-262. 
Makki, S., \& Somwaru, A. (2004). Impact of Foreign Direct Investment and Trade on Economic Growth American. Journal of Agricultural Economics, 86, 795-801.

Obwona, M.B. (2004). Foreign Direct Investment in Africa. In financing Pro-Poor Growth. AERC Senior Policy Seminar VI, Kampala Uganda, 2-4 March 2004: Seminar Papers, 6-95, Nairobi.

Olofsdotter, K. (1998). Foreign Direct Investment, Country Capabilities and Economic Growth. Weltwitschafliches Arckive, 134(3), 534-547.

Oyinlola, O. (1995). External capital and economic development in Nigeria (1970-1991). The Nigerian Journal of Economic and Social Studies, 37(2-3), 205-222.

Phillips, P.C.B., \& Perron, P. (1988). Testing for a unit root in time series regression. Biometrika, 75, 335-346.

Sahoo, K., \& Sethi, N. (2017). Impact of foreign capital on economic development in India: An Econometric Investigation. Global Business Review, 18(3), 1-15. doi: 10.1177/097 2150917692198.

Sanjaya, L., \& Rajneesh, N. (2004). Foreign Direct Investment and its Role in Economic Development: Do We Need a New Agenda? The European Journal of Development Research, 16(3), 447-464.

Shahbaz, M., \& Rahman, M.M. (2010). Foreign capital inflows-growth nexus and role of domestic financial sector: An ARDL co-integration approach for Pakistan. J. Econ. Res., 15, 207-231.

Umah, K.E. (2007). The Impact of Foreign Private Investment on Economic Development of Nigeria. Nigeria Journal of Economics and Financial Research, 11(3).

\title{
Article history:
}

Received: 30 January 2020

Revised: 25 February 2020

Accepted: 12 March 2020

\section{For citation:}

Madojemu, M. (2020). The role of foreign direct investment in economic growth of Nigeria. RUDN Journal of Economics, 28(2), 357-366. http://dx.doi.org/10.22363/2313-23292020-28-2-357-366

\section{Bio note:}

Michael Madojemu, PhD student in Economics of the International Economic Relations Department, Peoples' Friendship University in Russia (RUDN University). E-mail: agomado@, inbox.ru

\section{Влияние прямых иностранных инвестиций на экономический рост Нигерии}

\author{
М. Мадоджему \\ Российский университет дружбы народов \\ Российская Федераџия, 117198, Москва, ул. Миклухо-Маклая, 6
}

Исследование посвящено оценке влияния ПИИ на экономический рост Нигерии. В работе представлен анализ влияния ПИИ на такие сектора экономики Нигерии, как промышленный, добычи (нефть), телекоммуникационный; анализ степени влияния ПИИ 
на выбранные сектора основывается в том числе на теоретических подходах и научных работах, опубликованных в период с 1981 по 2017 г. Сформирован ряд рекомендаций, позволяющих «трансформировать» влияние ПИИ в социально-экономический рост Нигерии. Формирование благоприятной инвестиционной среды должно способствовать привлечению иностранных инвесторов в экономику Нигерии, главным образом через сокращение или устранение инвестиционных рисков, одним из которых является социальная безопасность.

Ключевые слова: ПИИ, экономический рост, экономика Нигерии, секторы экономики, инвестиционная политика

\section{История статьи:}

Дата поступления в редакцию: 30 января 2020

Дата проверки: 25 февраля 2020

Дата принятия к печати: 12 марта 2020

\section{Для цитирования:}

Madojeти М. The role of foreign direct investment in economic growth of Nigeria (Влияние прямых иностранных инвестиций на экономический рост Нигерии) // Вестник Российского университета дружбы народов. Серия: Экономика. 2020. Т. 28. № 2. С. 357-366. http://dx.doi.org/10.22363/2313-2329-2020-28-2-357-366

\section{Сведения об авторе:}

Мадоджему Майкл, аспирант кафедры vеждународных экономических отношений Российского университета дружбы народов. E-mail: agomado@inbox.ru 